[Review Paper]

\title{
Coke Formation on Zeolite Catalysts in Naphtha Cracking
}

\author{
Takayuki KOMATSU* \\ Dept. of Chemistry, School of Science, Tokyo Institute of Technology, 2-12-1-E1-10 Ookayama, Meguro-ku, Tokyo 152-8551, JAPAN
}

(Received August 4, 2017)

\begin{abstract}
Coke formation was investigated in the catalytic cracking of alkanes into light alkenes over ferrierite and ZSM5 zeolites. H-ferrierite had the highest alkene selectivity in heptane cracking because of its smaller pore size. $\mathrm{Ca}^{2+}$-exchange into $\mathrm{H}$-ferrierite improved the selectivity and controlled coke formation. $\mathrm{Ca}^{2+}$ ions located at the center of the 8-membered ring converted ferrierite pores into one-dimensional channels of 10-membered rings, which suppressed the bimolecular hydride transfer to form alkanes and coke precursors. H-ZSM-5 zeolites having various extents of coke deposited in hexane cracking were characterized by adsorption measurements of various alkane molecules. Small amounts of coke did not affect the hexane conversion and micropore volume, whereas the adsorption rate of 2,3-dimethylbutane decreased significantly. These results suggest that coke is accumulated on the external surface of H-ZSM-5. Most coke would be formed via aromatic hydrocarbons. Selectivity for the transformation of aromatics into coke correlated with crystallite size of H-ZSM-5, indicating that aromatics formed in short channels can diffuse out of the crystallite immediately without coke precursor formation. H-ZSM-5 with smaller crystallite size is likely to be a stable catalyst for naphtha cracking into light alkenes with adequate catalyst life.
\end{abstract}

\section{Keywords}

Catalytic cracking, Naphtha, Light alkene, Coke formation, Zeolite catalyst, External surface

\section{Introduction}

Light alkenes, such as propylene, are important raw materials in the petrochemical industry. Thermal cracking of naphtha has been the main supply source of these alkenes, but catalytic cracking of naphtha has the potential to satisfy the increasing demand for propylene. Catalytic cracking can be operated at lower temperatures and provides propylene with higher selectivity than thermal cracking. However, the performance of reported catalysts has not been satisfactory and requires improvement, especially in stability, for industrial use.

Zeolites are promising catalysts for naphtha cracking. Mono-molecular cracking is a typical reaction mechanism of high-temperature catalytic cracking as shown in Fig. 1(a) ${ }^{1)}$. However, reactive carbenium ions may react with alkenes during this reaction, resulting in the formation of undesirable alkanes and hydrogen deficient species, which are coke precursors (Fig. 1(b)). The USY zeolite widely used in the fluid catalytic cracking (FCC) process tends to promote this type of bimolecular hydride transfer. ZSM-5 has been added to USY to control hydride transfer in the cracking of vacuum gas oil'2),3). In contrast, ZSM-5 is not so

DOI: doi.org/10.1627/jpi.61.28

* E-mail: komatsu@chem.titech.ac.jp active for the hydride transfer and selective to lower alkenes due to the smaller channels. Further improvement of the stability of ZSM-5 in the cracking of naphtha model compounds has been based on addition of $\mathrm{P}^{4)}, \mathrm{K}$ or $\mathrm{Ba}^{5)}, \mathrm{Ga}^{6)}$, and $\mathrm{La} / \mathrm{P}^{7)}$.

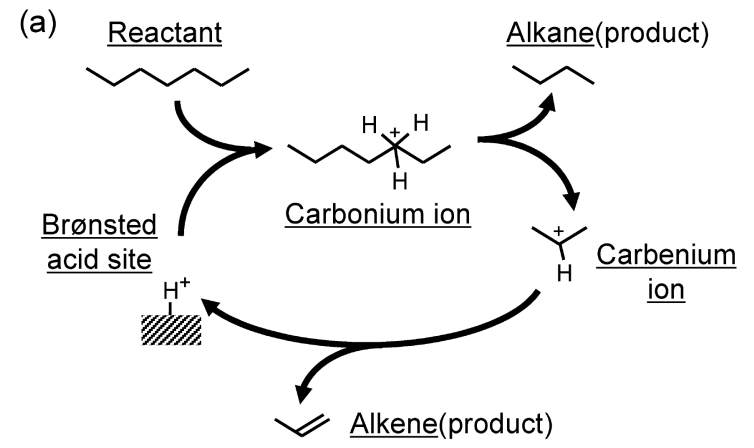

(b)

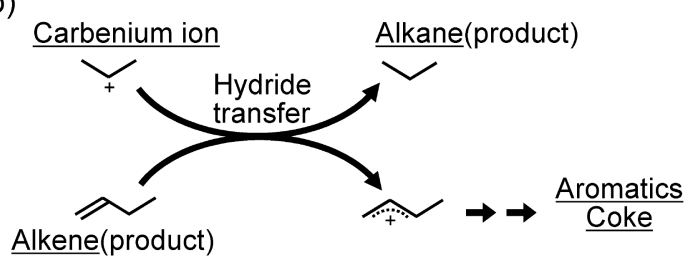

Fig. 1 Reaction Schemes of (a) Monomolecular Cracking and (b) Bimolecular Hydride Transfer in Alkane Cracking 


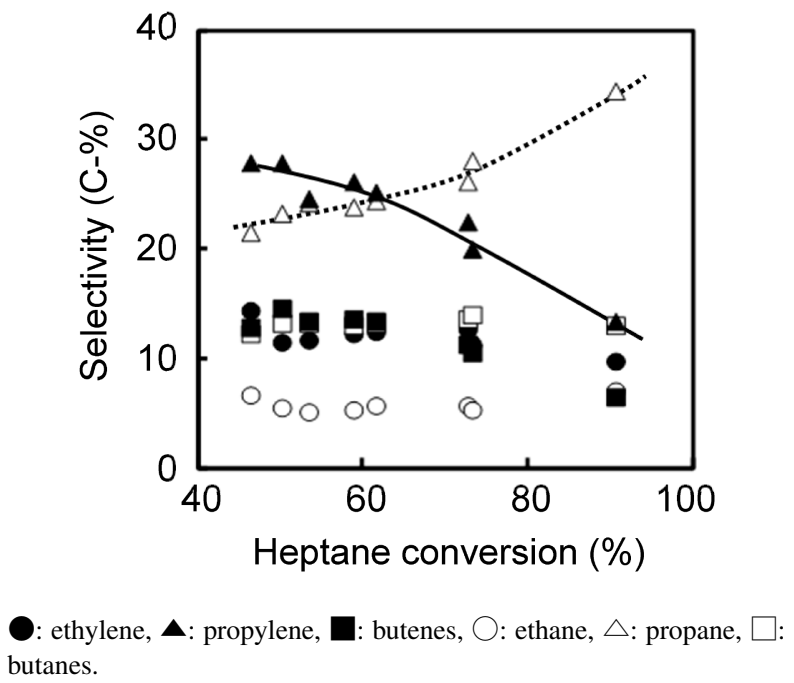
butanes.

Fig. 2 Changes in Selectivity with Heptane Conversion at $773 \mathrm{~K}$ over H-ZSM-5(22)

Other researchers have investigated the catalytic properties of zeolites with various pore sizes and dimensions, such as H-beta ${ }^{8)}$, H-MCM-229), H-MCM-68 ${ }^{10)}$, and H-ZSM-57 ${ }^{11)}$. Our previous study of the catalytic cracking of hexane, heptane and octane on various zeolites found that selectivity to light alkenes increased with decreasing pore size of the zeolites ${ }^{12)}$. Further study of ferrierite revealed the stabilizing effect of $\mathrm{Ca}^{2+}$-exchange, suggesting that the one-dimensional channel system is effective for the selective formation of light alkenes ${ }^{13)}$. However, the lifetime of $\mathrm{Ca}, \mathrm{H}$ ferrierite catalyst does not satisfy industrial requirements.

This paper summarizes our studies on ZSM-5 with intrinsic high activity and ferrierite with smaller pores in the catalytic cracking of alkanes. The purposes of this study are to clarify the locations of coke formation and deposition, to identify the intermediates which are transformed into coke, and to determine the mechanisms of coke formation ${ }^{14), 15)}$.

\section{Alkane Cracking over Ferrierite Catalyst}

Heptane cracking was carried out as a model reaction of naphtha cracking, using various zeolites as catalysts to investigate the effects of the size and morphology of the zeolite pores. Products were $\mathrm{C} 2-\mathrm{C} 4$ alkenes, $\mathrm{C} 1$ C4 alkanes and significant amounts of aromatic hydrocarbons. Selectivity to propylene remarkably decreased at higher heptane conversion, whereas propane selectivity increased inversely (Fig. 2), as expected from the hydride transfer between alkene molecules and carbenium ions (Fig. 1(b)). Hydride transfer not only converts alkenes into undesirable alkanes but also produces hydrogen deficient species, which will be the precursors of aromatics and coke. If most coke is formed

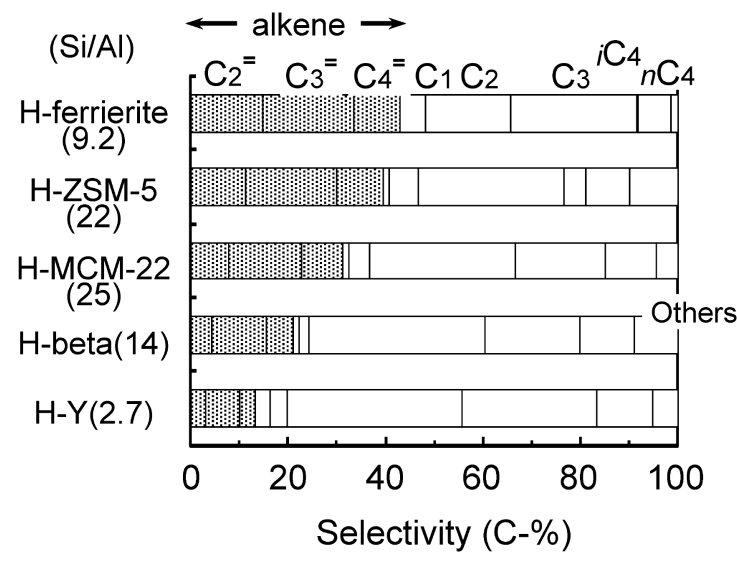

Heptane conversion: $80 \%, \mathrm{C} 1$ : methane, $\mathrm{C} 2$ : ethane, $\mathrm{C} 3$ : propane, $i$-C4: isobutane, $n$-C4: butane, $\mathrm{C} 2{ }^{=}$: ethylene, $\mathrm{C} 3^{=}$: propylene, $\mathrm{C} 4{ }^{=}$: butenes.

Fig. 3 Selectivities of Zeolite Catalysts in Heptane Cracking at $773 \mathrm{~K}$

through this route, the catalyst with the highest selectivity to alkenes even at high conversion will be the most stable catalyst with the least formation of coke. The selectivities of various proton-form zeolites in the cracking of heptane are shown in Fig. 3. To identify the pore structures promoting hydride transfer, the selectivity obtained at high conversion of $80 \%$ was compared. H-ferrierite provided the highest selectivity of $43 \mathrm{C}-\%$ to $\mathrm{C} 2-\mathrm{C} 4$ alkenes (gray bars). Alkene selectivity was in the following order;

$\mathrm{H}$-ferrierite $>\mathrm{H}-\mathrm{ZSM}-5>\mathrm{H}-\mathrm{MCM}-22>\mathrm{H}$-beta $>$ $\mathrm{H}-\mathrm{Y}$

This order is opposite to the order of pore size. Therefore, smaller pore size results in higher alkene selectivity. Because hydride transfer is a bimolecular reaction, it requires more space than a monomolecular reaction ${ }^{16)}$. The pores of $\mathrm{H}$-ferrierite are too small to allow an alkene molecule and a carbenium ion to collide in the appropriate configurations to transfer $\mathrm{H}^{-}$.

As the pore size affected the selectivity, pore dimension would also have significant effects on the hydride transfer. For example, one-dimensional pores or channels may hinder hydride transfer. Therefore, cracking of octane was investigated over various medium-pore zeolites with one-dimensional channels (H-ZSM-22, H-SAPO-11 and H-SAPO-31), two-dimensional channels (H-ferrierite), and three-dimensional channels (H-ZSM-5). Figure 4 shows the selectivity obtained at high conversion $(>95 \%)$. One-dimensional zeolites all achieved higher selectivity to $\mathrm{C} 2-\mathrm{C} 4$ alkenes than two- and three-dimensional zeolites. In onedimensional channels with small diameters, one molecule cannot easily overtake another molecule, which would decrease the frequency of the collisions between alkene molecules and carbenium ions necessary for 


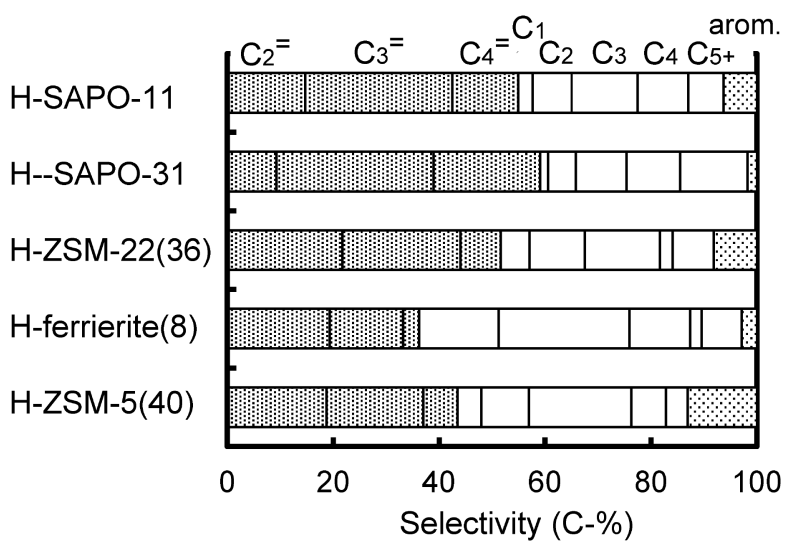

Octane conversion $>95 \%$. arom. $=$ aromatics. See captions of Fig. 3.

Fig. 4 Selectivities of Zeolites with Various Pore Dimensions in Octane Cracking at $773 \mathrm{~K}$

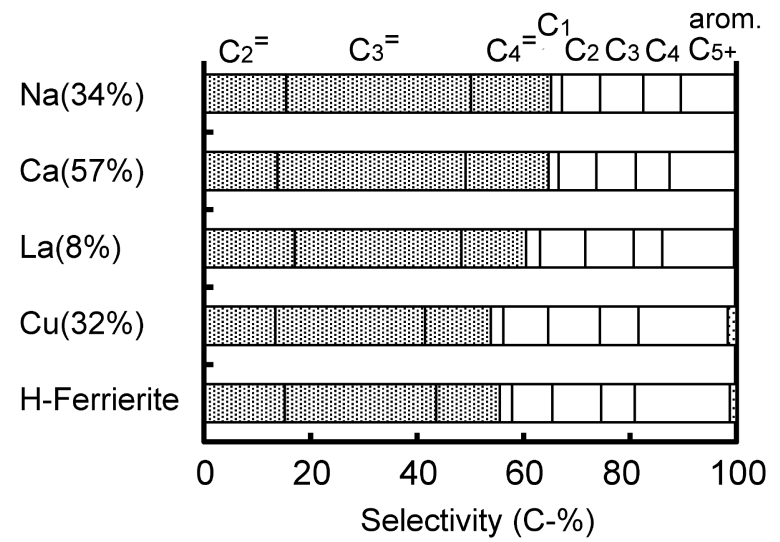

Cation-exchange levels are in parentheses. See captions of Figs. 3 and 4 .

Fig. 5 Selectivities of Cation-exchanged Ferrierite in Octane Cracking at $773 \mathrm{~K}$

hydride transfer. In addition, molecules cannot easily rotate into the appropriate orientation for hydrogen transfer because of the absence of relatively wide intersection spaces with other channels.

These findings suggest that the pore size and dimensions are important factors which physically affect hydride transfer. To investigate the effects of the chemical properties of zeolite on hydride transfer, various cations were introduced by ion-exchange into ferrierite. Alkene selectivity in octane cracking was improved by ion-exchange with $\mathrm{La}^{3+}, \mathrm{Ca}^{2+}$ and $\mathrm{Na}^{+}$ (Fig. 5). Hydride transfer was effectively controlled by such ion-exchange. Such catalysts will achieve high stability due to the low concentration of coke precursor formed through hydride transfer. Figure 6 shows the change in octane conversion with time on

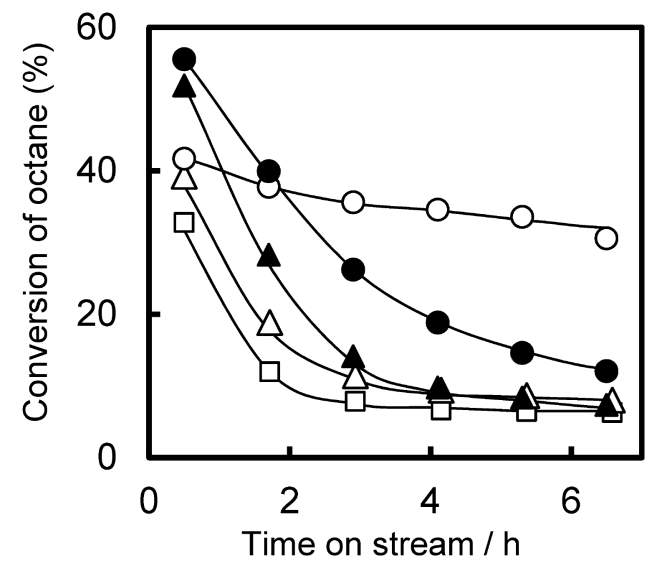

Fig. 6 Changes in Octane Conversion with Time on Stream over $\mathrm{H}$-ferrierite $(\boldsymbol{\Delta})$ and $\mathrm{H}$-ferrierite Exchanged with $\mathrm{Na}^{+}$ $(34 \%)(\bigcirc), \mathrm{Ca}^{2+}(57 \%)(\bigcirc), \mathrm{La}^{3+}(8 \%)(\triangle)$, and $\mathrm{Cu}^{2+}$ $(52 \%)(\square)$

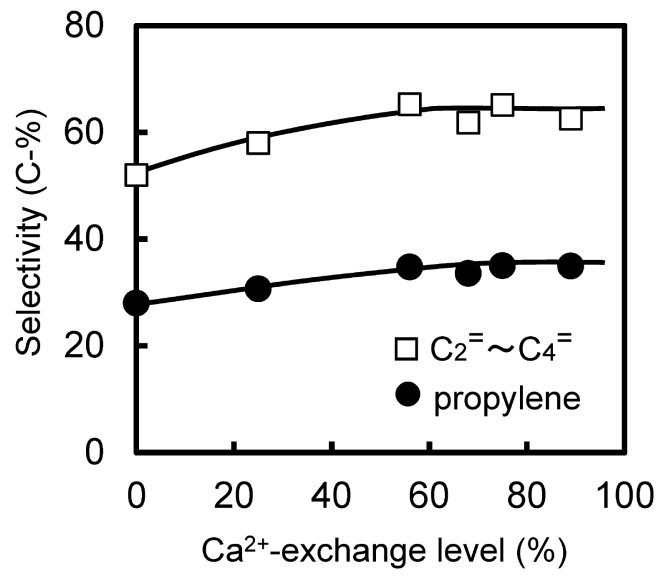

Fig. 7 Changes in Initial Selectivities to Propylene $(O)$ and $\mathrm{C} 2=$ $\mathrm{C} 4=$ alkenes $(\square)$ with $\mathrm{Ca}^{2+}$-exchange Level for Octane Cracking over $\mathrm{Ca}, \mathrm{H}$-ferrierite at $773 \mathrm{~K}$

stream. H-ferrierite showed rapid decrease in conversion and became almost inactive within a few hours on stream. In contrast, $\mathrm{Ca}, \mathrm{H}$-ferrierite exhibited significant improvement in stability of conversion. Similar improvement in selectivity and stability was obtained for heptane cracking ${ }^{12)}$. Clearly, $\mathrm{Ca}^{2+}$ ions in ferrierite channels inhibit hydride transfer and prevent the formation of undesirable alkanes and coke.

To investigate the suppression of hydride transfer, $\mathrm{Ca}, \mathrm{H}$-ferrierite was prepared with various exchange levels and applied to octane cracking. Figure 7 shows the change in initial selectivity to alkenes and propylene with $\mathrm{Ca}^{2+}$-exchange level. Selectivity to propylene and alkenes increased with increasing $\mathrm{Ca}^{2+}$ exchange level and reached steady state at around 65 C-\% with exchange level of $50 \%$. As an index of catalyst stability, decrease in conversion from 0.5 to $6.6 \mathrm{~h}$ on stream was compared with the amount of coke 
(Fig. 8). Decrease in conversion did not change up to $25 \%$ exchange level then decreased at higher exchange level. The amount of coke decreased with $\mathrm{Ca}^{2+}$ exchange level similarly to the decrease in conversion. Figure 8 suggests that the decrease in conversion with time on stream is caused by the accumulation of coke and that coke formation is effectively controlled by $\mathrm{Ca}^{2+}$ exchange. As already shown in Fig. 7, increase in alkene selectivity is not noticeable after $\mathrm{Ca}^{2+}$ exchange of $50 \%$. Cracking of an alkane molecule must produce one alkane and one alkene molecule (Fig. 1(a)). Therefore, a significant amount of alkane must be produced even if no hydride transfer occurs. For example, if all hexane molecules are decomposed into $\mathrm{C} 2$ hydrocarbons, the products will have a $\mathrm{C} 2=/ \mathrm{C} 2$ ratio of two, corresponding to alkene selectivity of $67 \mathrm{C}-\%$. This value is close to that achieved over $\mathrm{Ca}, \mathrm{H}$-ferrierite. Therefore, further $\mathrm{Ca}^{2+}$-exchange will not increase the selectivity.

Ferrierite consists of two-dimensional channels with ten-membered ring (10-MR) and 8-MR openings, but the alkene selectivity of $\mathrm{Ca}, \mathrm{H}$-ferrierite was comparable to that of zeolites with one-dimensional channels, SAPO-31 and ZSM-22 (Fig. 4). Therefore, exchanged $\mathrm{Ca}^{2+}$ may be located at the specific position to hinder

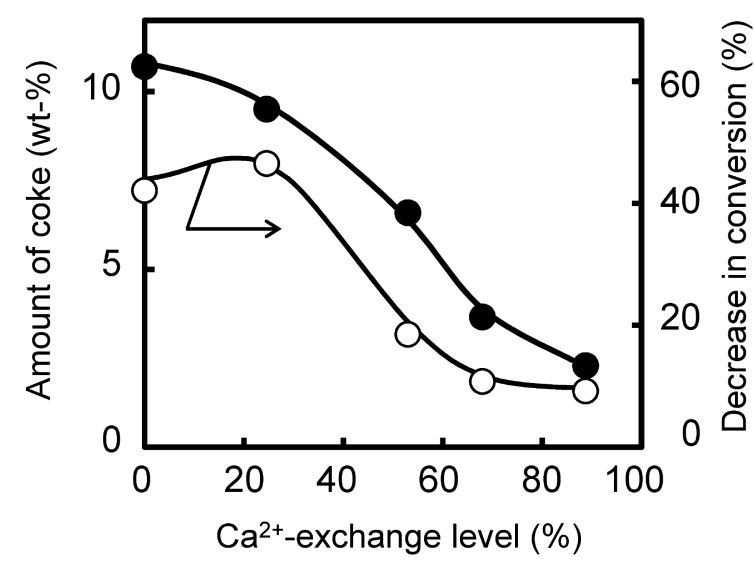

Fig. 8 Changes in Amount of Coke (O) and Decrease in Conversion $(\mathrm{O})$ with $\mathrm{Ca}^{2+}$-exchange Level for $6.6 \mathrm{~h}$ of Octane Cracking over $\mathrm{Ca}, \mathrm{H}$-ferrierite at $773 \mathrm{~K}$ the diffusion of molecules through the smaller 8-MR channels. This effect would transform ferrierite into a one-dimensional zeolite with a 10-MR channel system (Fig. 9). To confirm this idea, high-resolution, hightemperature powder X-ray diffraction data was collected for $\mathrm{Ca}(89 \%), \mathrm{H}$-ferrierite at $673 \mathrm{~K}$ to eliminate any adsorbed water molecules in micropores. Obtained data were analyzed by the Rietveld method using the program RIETAN-FP ${ }^{17)}$. The findings showed that $\mathrm{Ca}^{2+}$ cations were located at two different positions: the center of the 8-MR channel (Ca1) near the intersection with 10-MR channels, in accordance with position ' $F$ ' ${ }^{18)}$; and in the wall between the 5-MR pores and 8-MR channels $(\mathrm{Ca} 2) . \mathrm{Ca}^{2+}$ cations at $\mathrm{Ca} 1$ site must block the 8 -MR channels and prevent the diffusion of molecules through these channels, whereas $\mathrm{Ca}^{2+}$ at $\mathrm{Ca} 1$ and $\mathrm{Ca} 2$ sites will not affect the pore size of the 10-MR channels. The above findings support the idea that $\mathrm{Ca}^{2+}$ exchange transforms ferrierite into one-dimensional pore zeolite, resulting in high alkene selectivity and low coke formation rate.

\section{Coke Formation on H-ZSM-5 during Alkane Cracking}

Zeolites with one-dimensional channels show high selectivity for light alkene formation in naphtha cracking. Hydride transfer between alkene and carbenium ion is strongly hindered in the one-dimensional channels, resulting in reduced formation of undesirable alkanes, aromatics and coke. However, zeolites with one-dimensional channels have disadvantages in activity for commercial use because the diffusion of molecules must be limited by the slowest bulky molecule in the same channel. In contrast, H-ZSM-5 with threedimensional pores showed the highest activity in the cracking of heptane and octane with high alkene selectivity comparable to $\mathrm{H}$-ferrierite. No catalyst active for alkane cracking but totally inactive for coke formation has been discovered. However, detailed understanding of the mechanism and active sites for coke formation on H-ZSM-5 will minimize the amount and/or effect of coke, thus maintaining high activity and selec-

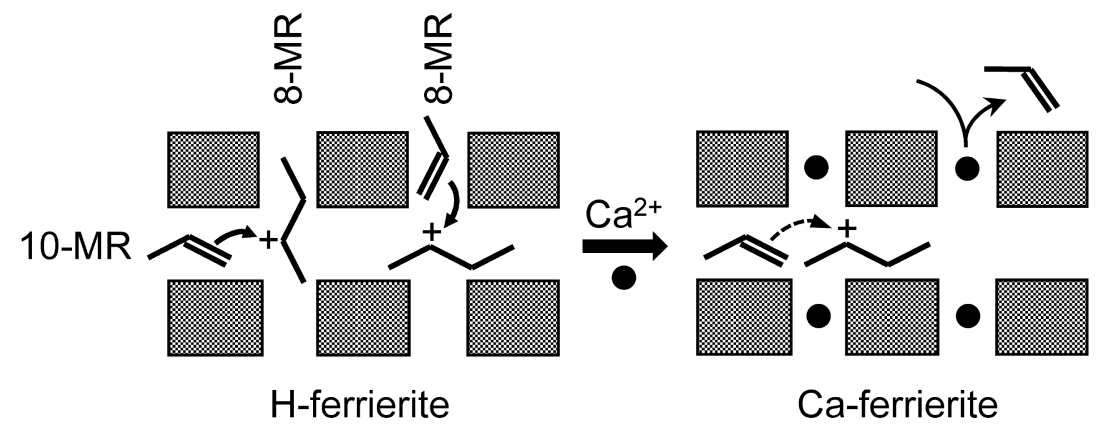

Fig. 9 Model for Hydride Transfer in Channels of $\mathrm{Ca}^{2+}$-exchanged $\mathrm{H}$-ferrierite 


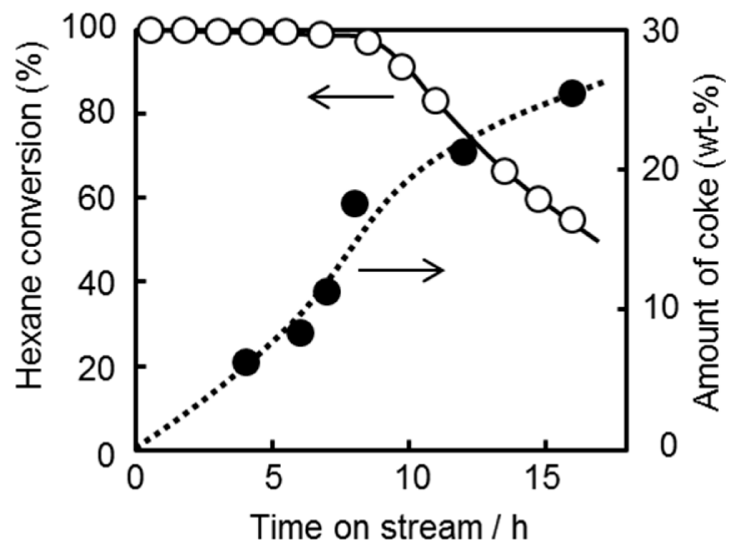

Fig. 10 Changes in Hexane Conversion $(\bigcirc)$ and the Amount of Coke (O) with Time on Stream in Hexane Cracking over H-ZSM-5(23) at $948 \mathrm{~K}$

tivity for adequate on stream periods. Therefore, the mechanisms of coke formation on H-ZSM-5 are discussed based on the results of adsorption measurements using H-ZSM-5 partially deactivated by coke deposition during hexane cracking.

Cracking of hexane was carried out at $948 \mathrm{~K}$ over $\mathrm{H}-\mathrm{ZSM}-5(\mathrm{Si} / \mathrm{Al}=23)$. Under these conditions, the initial conversion was $100 \%$ (Fig. 10). In contrast, thermal cracking without catalysts gave $34 \%$ conversion. The activity of H-ZSM-5 apparently did not decrease for several hours on stream, but coke formation started from the initial stage (filled circles). At $16 \mathrm{~h}$ on stream, the amount of coke reached $26 \mathrm{wt} \%$ and the conversion fell to $56 \%$.

The location of coke deposition, inside or outside the pores, was investigated by measuring micropore volume with nitrogen adsorption for H-ZSM-5(23) used in hexane cracking for 4-16 h, corresponding to the filled circles in Fig. 10. Micropore volume of the cokedeposited H-ZSM-5 was plotted against the amount of coke in Fig. 11. Fresh H-ZSM-5 had a volume of $0.155 \mathrm{~mL} \mathrm{~g}^{-1}$. The deposition of $7 \mathrm{wt} \%$ coke did not greatly decrease the micropore volume, which may be acceptable if most of the coke is located on the external surface, that is, outside the micropores. The two dotted lines indicate the calculated micropore volume assuming that all coke is located inside the pores and that the density of coke is same as that of graphite $(2.2 \mathrm{~g}$ $\left.\mathrm{cm}^{-3},(\mathrm{a})\right)$ or liquid hydrocarbon $\left(0.7 \mathrm{~g} \mathrm{~cm}^{-3},(\mathrm{~b})\right)$. The micropore volume of H-ZSM-5 with $7 \mathrm{wt} \%$ coke was larger than the upper line (a), which strongly supports the idea of coke deposition on the external surface. The micropore volume decreased with higher coke amount. Such coke deposition can occur as two possibilities; coke begins to deposit inside the pores or the external surfaces of some crystallites are fully covered by coke. To assess whether the pore openings of H-ZSM-5 were covered by coke accumulated on the

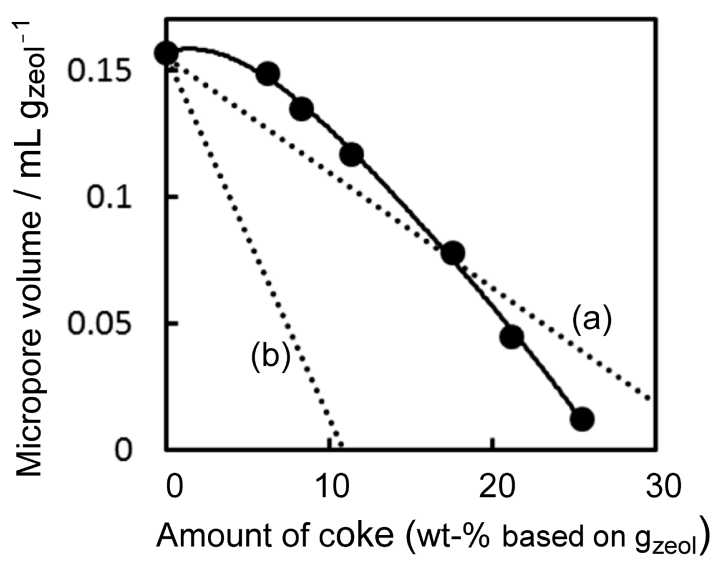

Dotted lines are calculated values assuming that all coke is located inside pores with coke density of $2.2 \mathrm{~g} \mathrm{~cm}^{-3}$ (a) and $0.7 \mathrm{~g} \mathrm{~cm}^{-3}$ (b).

Fig. 11 Effect of Amount of Coke on Micropore Volume of H-ZSM-5(23)

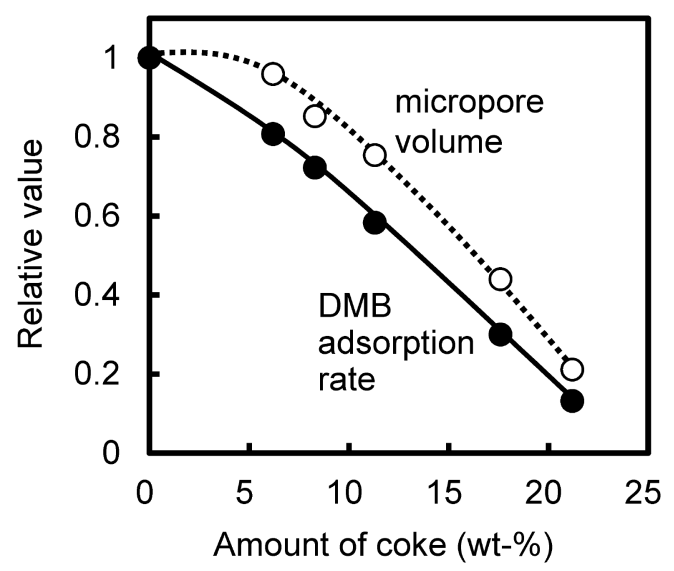

Fig. 12 Changes in DMB Adsorption Rate (O) and Micropore Volume ( $\bigcirc$ ) for Coke-deposited H-ZSM-5(23) in Hexane Cracking at $948 \mathrm{~K}$

surface, the adsorption of a bulky molecule, 2,3-dimethylbutane (DMB), was measured. At room temperature, adsorption of hexane reached its equilibrium within $5 \mathrm{~min}$, whereas adsorption of DMB proceeded very slowly to reach its equilibrium after 30 min. Therefore, the initial rate of DMB adsorption will not be affected by the coke inside the pores. In contrast, the coke outside the pores would cover an appreciable number of pore openings, resulting in reduced initial adsorption rate. Therefore, DMB adsorption rate can be considered as an index of the number of pore openings. The solid line in Fig. 12 shows the change in the initial rate of DMB adsorption with the amount of coke. The dotted line indicates micropore volume as shown in Fig. 11. Both are relative values taking the values for fresh H-ZSM-5 as unity. Clearly the rate of DMB adsorption decreased with increasing coke amount from the initial stage. This 


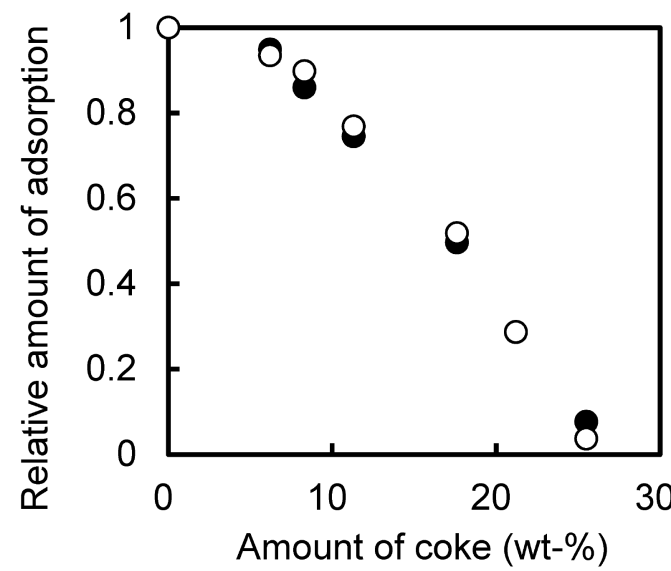

Fig. 13 Changes in the Relative Amount of Adsorption of Hexane (O) and 2-Methylpentane $(\bigcirc)$ on Coke-deposited H-ZSM-5(23) on Hexane Cracking at $948 \mathrm{~K}$

observation also supports the idea that most of the coke is located on the external surface if the amount of coke is not so large.

Locations of large amounts of coke only on the external surface or in the pores were investigated by measuring the adsorption of hexane and 2-methylpentane on the coke-deposited H-ZSM-5(23). The amounts of these alkanes adsorbed on fresh H-ZSM-5 were $0.155 \mathrm{~mL} \mathrm{~g}^{-1}$ and $0.108 \mathrm{~mL} \mathrm{~g}^{-1}$, respectively. Relative amount of adsorption was calculated taking these values as unity. Figure 13 clearly shows that the relative values decreased similarly for both adsorbates with higher coke deposition. Because these alkanes have different molecular diameters, coke inside the pores would affect their adsorption to different extents. The definite similarity shown in Fig. 13 strongly suggests that most coke is located on the external surface of H-ZSM-5 even exceeding $15 \mathrm{wt} \%$. Coke formation was reported to mainly occur on the external surface of H-ZSM-5 during hexane cracking based on the finding that smaller H-ZSM-5 crystallites formed larger amounts of coke ${ }^{19)}$. In contrast, coke was formed at the intersection of two channels in heptane cracking ${ }^{20)}$.

Figure 14 shows our proposed model of coke accumulation on H-ZSM-5 based on the above results. At the initial stage, coke is formed on the external surface and does not greatly affect catalytic activity. In the middle stage, some H-ZSM-5 crystallites are fully covered by coke and lose catalytic activity. The coke will accumulate on the external surface until all crystallites are fully covered. If coke is formed as shown in Fig. 14, H-ZSM-5 with smaller crystallite size must have longer catalyst life because covering the larger number of pore openings takes longer time. Therefore, we prepared H-ZSM-5 with different Si/Al ratios $(23,62$ and 107$)$ to alter the crystallite size. Figure 15 shows the time course of DMB adsorption

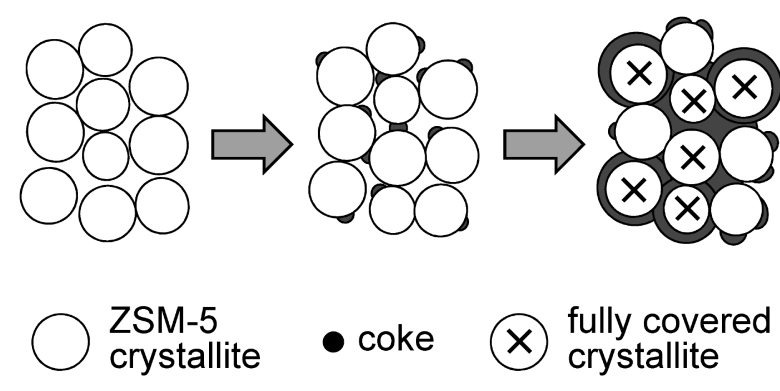

Fig. 14 Model of Coke Deposition and Accumulation on ZSM-5 Crystallites during Alkane Cracking

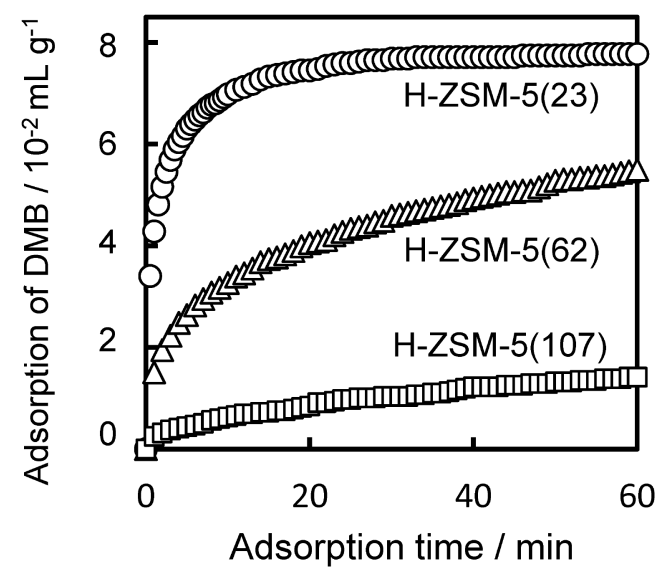

Fig. 15 Time Course of 2,3-Dimethylbutane Adsorption on H-ZSM-5

on such H-ZSM-5 catalysts. As mentioned above, the initial rate of DMB adsorption correlates with the number of pore openings. The initial rates were in the following order;

H-ZSM-5(23) > H-ZSM-5(62) > H-ZSM-5(107)

Therefore, the crystallite size must be in the reverse order;

H-ZSM-5(107) > H-ZSM-5(62) > H-ZSM-5(23)

These H-ZSM-5 catalysts were used for hexane cracking (Fig. 16(a)). Conversion decreased with increasing coke amount on every catalyst, but H-ZSM-5 with smaller crystallite size achieved higher conversion at the same coke amount. The higher activity caused by the slower deactivation of H-ZSM-5 with smaller crystallite size has been reported previously for the hexane cracking $^{21)}$. The slow deactivation was explained by the shorter diffusion paths and larger number of pore openings. Micropore volumes of each H-ZSM-5 decreased with increasing coke amount (Fig. 16(b)). H-ZSM-5(107) with the largest crystallite size lost micropore volume rapidly after deposition of a small amount of coke, whereas H-ZSM-5(23) lost a similar micropore volume only after deposition of more than twice the amount of coke. Clearly H-ZSM-5 with larger external surface area possesses longer catalyst 

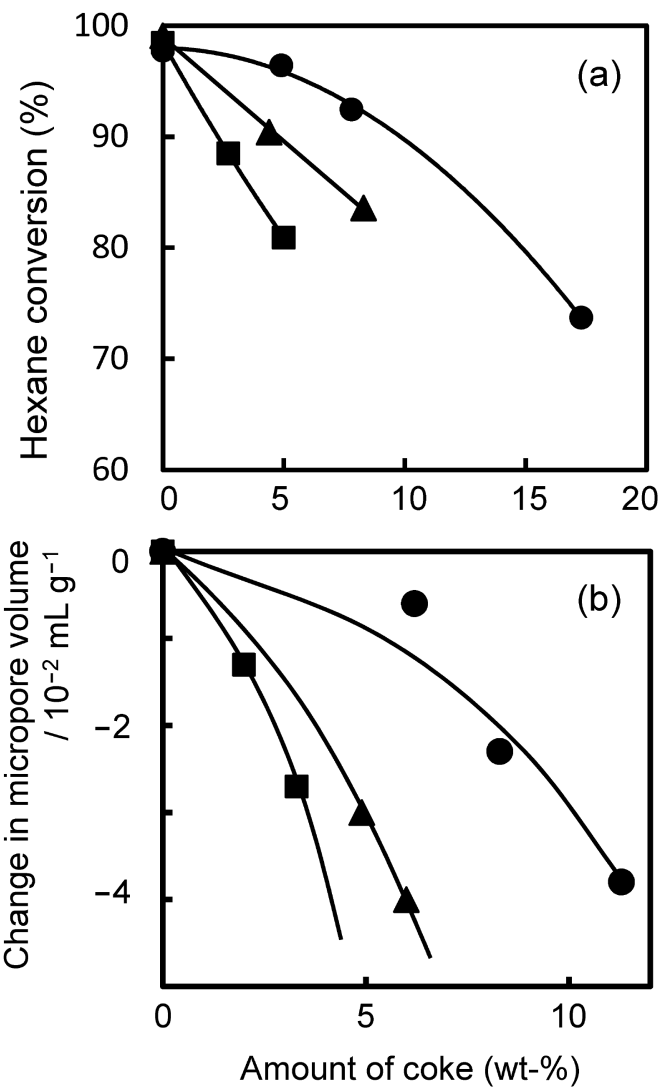

Fig. 16 Effects of Coke Amount on Hexane Conversion (a) and Micropore Volume (b) for H-ZSM-5(23) (O), H-ZSM-5(62) (A) and H-ZSM-5(107)

life.

These findings suggest that most coke is located on the external surface of H-ZSM-5. The nature of the coke precursor and the mechanism of coke formation were investigated based on the results obtained in the cracking of methylcyclohexane (MCH) and methylcyclopentane (MCP), compared with those of hexane cracking. H-ZSM-5(107) was used because its largest crystallite size would emphasize the effect of coke. Figure 17 shows the relationship between coke amount and accumulated amount of converted reactants. Each reactant gave a straight line with slope corresponding to the average selectivity to coke. Coke selectivity was in the following order;

$\mathrm{MCH}>\mathrm{MCP}>$ hexane

suggesting that cyclic molecules tend to be transformed into coke.

Cracking of hexane, MCH and MCP showed that selectivity changed with conversion as similarly to heptane cracking (Fig. 2). The common results were reduced propylene and butene selectivity at higher conversion and corresponding increase in selectivity to benzene, toluene and xylene (BTX). The reactants were transformed into $\mathrm{C} 3$ or $\mathrm{C} 4$ alkenes and successive reaction of these alkenes formed BTX. Figure $\mathbf{1 8}$

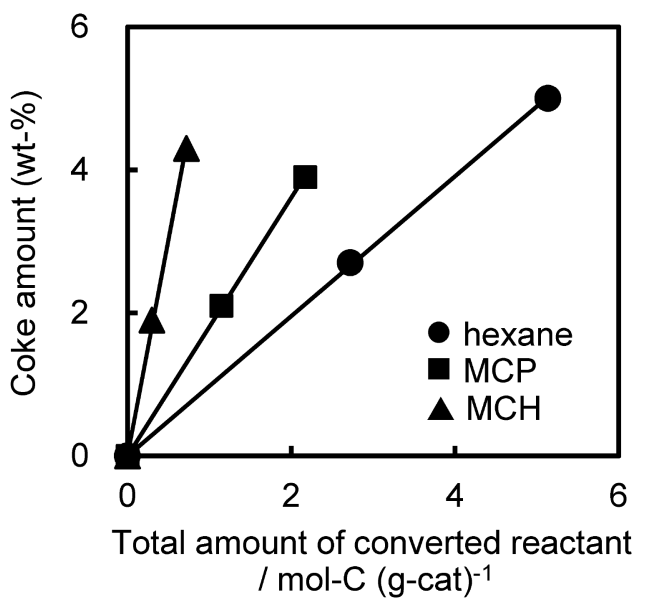

Fig. 17 Relationship between Coke Amount and Total Amount of Converted Reactant over H-ZSM-5(107)

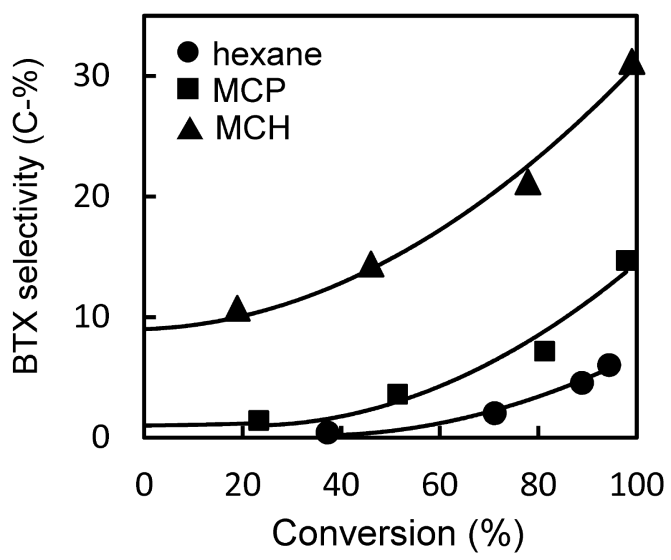

Fig. 18 Changes in BTX Selectivity with Hexane Conversion over H-ZSM-5(107)

shows the change in BTX selectivity with conversion of the three reactants. Extrapolation of each curve to $0 \%$ conversion would give the initial BTX selectivity. $\mathrm{MCH}$ had initial BTX selectivity of about $9 \mathrm{C}-\%$. There should be a direct route from $\mathrm{MCH}$ to BTX. In the case of MCP, there could be a slight contribution of direct formation of BTX. In contrast, all BTX will be secondary products in hexane cracking.

Reaction paths are described in Fig. 19. In addition to the BTX formation route, the final form of BTX is also included. Most BTX formed inside pores $\left(\mathrm{BTX}_{\mathrm{f}}\right)$ diffuses out of the pore intact to become product $\left(\mathrm{BTX}_{\mathrm{p}}\right)$, whereas part of $\mathrm{BTX}_{\mathrm{f}}$, indicated as BTX, is converted into coke on the external surface. Coke amounts obtained in the cracking of three reactants are plotted against the integrated amounts of BTX in Fig. 20. The data obtained with different reactants seemed to form a single straight line. The slope of this line indicated that only $1.4 \mathrm{wt} \%$ of $\mathrm{BTX}_{\mathrm{f}}$ was further converted into coke. This value will be described as 


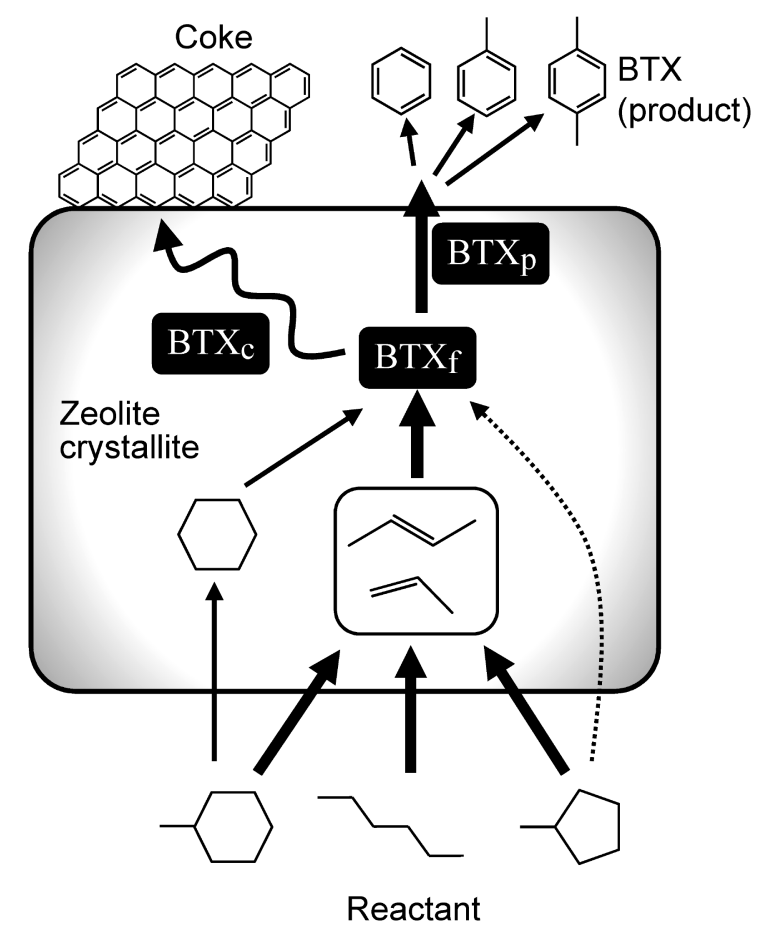

Fig. 19 Reaction Routes for Coke and BTX Formation in Alkane Cracking over H-ZSM-5

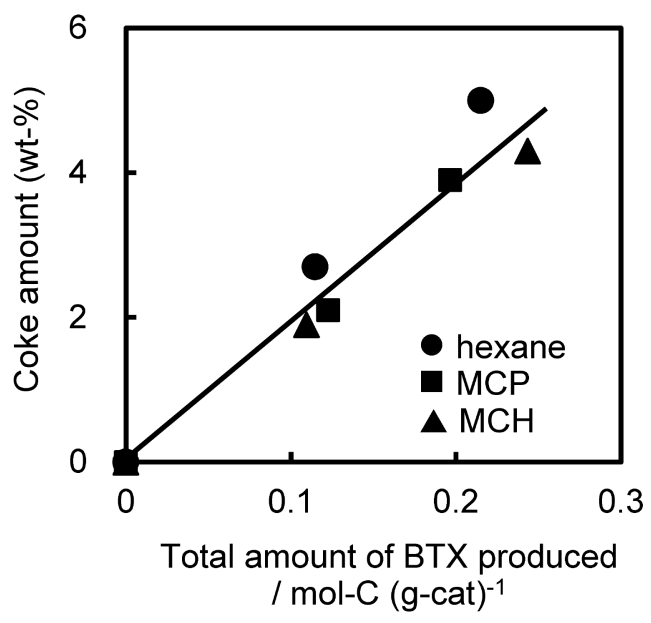

Fig. 20 Relationship between Coke Amount and Total Amount of BTX

$\mathrm{BTX}_{\mathrm{c}} / \mathrm{BTX}_{\mathrm{f}}=0.014$, which can be taken as the selectivity for coke formation from $\mathrm{BTX}_{\mathrm{f}}$ and described as $\mathrm{S}_{\mathrm{BTX}}$ (coke). Almost the same slope for the three reactants indicates that the nature of reactant molecules does not affect the coke selectivity, $\mathrm{S}_{\mathrm{BTX}}$ (coke).

Our finding that coke is formed through BTX indicates that the stable cracking catalyst will not produce BTX or will not convert BTX into coke, that is, $\mathrm{S}_{\mathrm{BTX}}($ coke $)=0$. Because the latter condition has been little studied, we tried to obtain catalyst with low $\mathrm{S}_{\mathrm{BTX}}($ coke $) . \quad \mathrm{H}-\mathrm{ZSM}-5(\mathrm{Si} / \mathrm{Al}=23,51,62,107)$ was
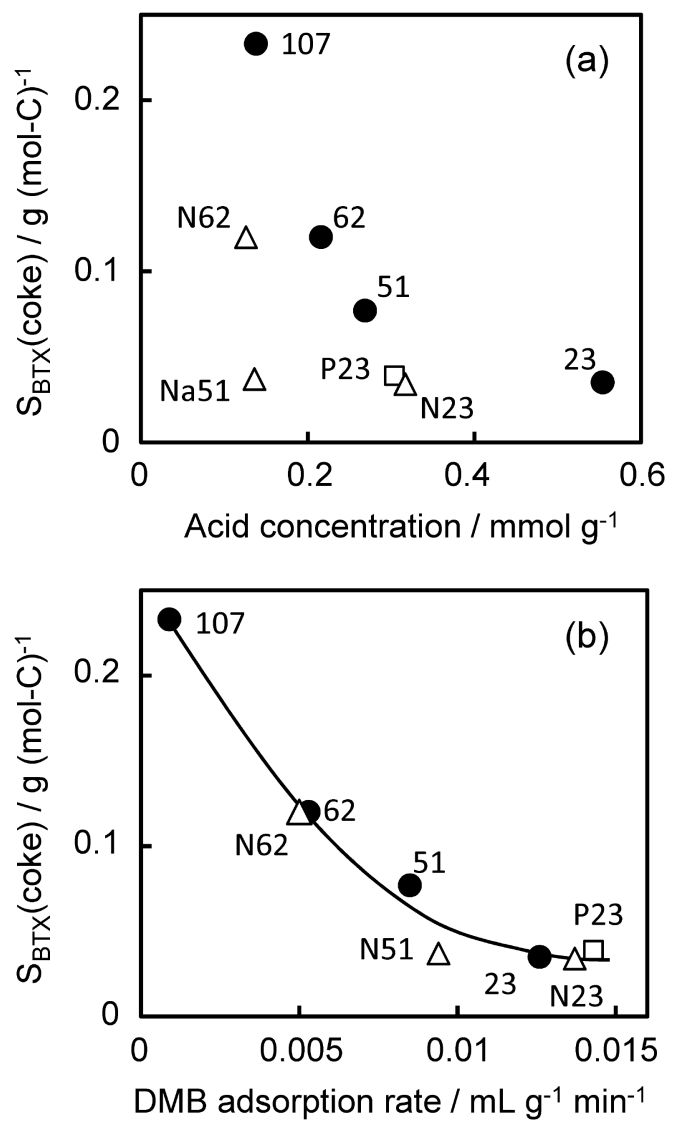

Fig. 21 Effect of Acid Concentration (a) and DMB Adsorption Rate (b) on Coke Selectivity, $\mathrm{S}_{\mathrm{BTX}}$ (coke)

prepared with various acid concentrations, by $\mathrm{Na}^{+}$ionexchange and phosphorus modification ${ }^{15)}$. Figure 21 shows the effects of acid concentration (a) and initial adsorption rate of DMB (b) on $\mathrm{S}_{\mathrm{BTX}}$ (coke). The acid concentration did not affect $S_{\text {ВTх }}($ coke), as is clear for H-ZSM-5(23) and H-ZSM-5(62) before and after $\mathrm{Na}^{+}$exchange. In contrast, the DMB adsorption rate showed a clear correlation with $\mathrm{S}_{\mathrm{BTx}}($ coke). As mentioned above, the DMB adsorption rate provides an index for crystallite size of H-ZSM-5, that is, higher adsorption rate indicates smaller crystallite size. Therefore, the clear correlation in Fig. 21(b) indicates that H-ZSM-5 with smaller crystallite size has lower $\mathrm{S}_{\mathrm{BTx}}$ (coke) and is likely to form a stable and active catalyst for naphtha cracking with minimum coke formation.

\section{Conclusion}

Catalytic cracking of alkanes was studied to evaluate coke formation using ferrierite and ZSM-5 zeolites. Coke formation through hydride transfer is effectively suppressed over zeolite catalysts with narrow inner space and one-dimensional channel morphology. Coke is deposited on the external surfaces of H-ZSM-5 
via formation of aromatic hydrocarbons. Most aromatics formed in zeolite pores diffuse out from the pores to be products, whereas only part of the aromatics are transformed into the precursor of coke deposited on the external surface. H-ZSM-5 with smaller crystallite size provides aromatic molecules formed inside pores with immediate diffusion and escape out of pores to prevent coke and its precursor formation. Very small crystallites of H-ZSM-5 are likely to form an active and selective catalyst for naphtha cracking without rapid deactivation by coke.

\section{Acknowledgment}

This work was financially supported by NEDO (New Energy and Industrial Technology Development Organization).

\section{References}

1) Haag, W. O., Dessau, R. M., Proc. 8th Intern. Congr. Catal., Berlin, 1984, vol. 2, p. 305.

2) Buchanan, J. S., Catal. Today, 55, 207 (2000).

3) Corma, A., Melo, F. V., Sauvanaud, L., Ortega, F. J., Appl. Catal. A: General, 265, 195 (2004).

4) Degnan, T. F., Chitnis, G. K., Schipper, P. H., Microporous Mesoporous Mater, 35-36, 245 (2000).

5) Wang, L., Xie, M., Tao, L., Catal. Lett., 28, 61 (1994).

6) Rane, N., Kersbulck, M., van Santen, R. A., Hensen, E. J. M., Microporous Mesoporous Mater., 110, 279 (2008).
7) Yoshimura, Y., Kijima, N., Hayakawa, T., Murata, K., Suzuki, K., Mizukami, F., Matano, K., Konishi, T., Oikawa, T., Saito, M., Shiojima, T., Shiozawa, K., Wakui, K., Sawada, G., Sato, K., Matsuo, S., Yamaoka, N., Catal. Surv. Jpn., 4, 157 (2000).

8) Nakao, R., Kubota, Y., Katada, N., Nishiyama, N., Kunimori, K., Tomishige, K., Catal. Lett., 89, 153 (2003).

9) Corma, A., GonzBlez-Alfaro, V., Orchilles, A. V., Appl. Catal. A: General, 129, 203 (1995).

10) Inagaki, S., Takechi, K., Kubota, Y., Chem. Commun., 46, 2662 (2010).

11) Lee, S., Lee, D., Shin, C., Paik, W. C., Lee, W. M., Hong, S. B., J. Catal., 196, 158 (2000).

12) Komatsu, T., Ishihara, H., Fukui, Y., Yashima, T., Appl. Catal. A: General, 214, 103 (2001).

13) Wang, L., Ozawa, K., Komatsu, T., Ikeda, T., Appl. Catal., A: General, 407, 127 (2011).

14) Urata, K., Furukawa, S., Komatsu, T., Appl. Catal., A: General, 475, 335 (2014).

15) Javaid, R., Urata, K., Furukawa, S., Komatsu, T., Appl. Catal., A: General, 491, 100 (2015).

16) Haag, W. O., Lago, R. M., Weisz, P. B., Faraday Disc. Chem. Soc., 72, 317 (1982).

17) Izumi, F., Momma, K., Solid State Phenom., 130, 15 (2007).

18) Mortier, W. J., "Compilation of Extraframework Sites in Zeolites," Butterworths, London (1982).

19) Konno, H., Okamura, T., Kawahara, T., Nakasaka, Y., Tago, T., Masuda, T., Chem. Eng. J., 207-208, 490 (2012).

20) Guisnet, M., Costa, L., Ribeiro, F. R., J. Mol. Catal., A: Chem., 305, 69 (2009).

21) Mochizuki, H., Yokoi, T., Imai, H., Watanabe, R., Namba, S., Kondo, J. N., Tatsumi, T., Microporous Mesoporous Mater., 145,165 (2011).

要旨

\author{
ナフサのクラッキングにおけるゼオライト触媒上でのコーク形成 \\ 小松 隆之 \\ 東京工業大学理学院化学系，152-8551 東京都目黒区大岡山2-12-1-E1-10
}

\begin{abstract}
アルカンのクラッキングによる低級アルケン生成に伴うコー ク形成について，フェリエライトおよびZSM-5に着目して詳 細に研究した。細孔径が小さい H-フェリエライトがヘプタン のクラッキングにおいて最も高いアルケン選択性を示し, $\mathrm{Ca}^{2+}$ 交換するとその選択性と安定性がさらに向上した。 $\mathrm{Ca}^{2+}$ が 8 員 環細孔をふさぐサイトに位置することにより，フェリエライト が 10 員環による 1 次元細孔のみをもつようになる。その結果, 2分子反応であるヒドリド移動が抑制され，アルカンやコーク 前駆体が形成されにくくなると考えられる。コークが何から形 成され，どこに蓄積されるかを明らかにするため，コーク含有 量および結晶子径が異なる H-ZSM-5 上で，種々のアルカン分
\end{abstract}

子の吸着実験を行った。少量のコーク堆積は, ヘキサン転化率 とミクロ孔容積には影響を及ぼさず，2,3-ジメチルブタンの吸 着速度を低くした。以上の結果から, コークが H-ZSM-5の外 表面のみに堆積すること, 細孔内で生成した芳香族分子の一部 がコーク前駆体へと変換され，外表面でコークとなり蓄積する ことを明らかにした。芳香族がコークに変換される割合と H-ZSM-5 結晶子の大きさとの相関から, 短いチャネル内で生 成した芳香族分子は，コーク前駆体へと転化する前に細孔から 容易に出られることが明らかとなった。小さな結晶子径をもつ H-ZSM-5 がナフサからのアルケン生成に対して耐久性をもつ 有効な触媒となり得ると結論した。 